\title{
Surfaces
}

\section{Humanism as the Theme of Chinese Modernity}

\section{Wang Hui}

Volume 5, 1995

DEUXIÈME CONGRÈS INTERNATIONAL SUR LE DISCOURS HUMANISTE (1995)

SECOND INTERNATIONAL CONFERENCE ON HUMANISTIC DISCOURSE (1995)

URI : https://id.erudit.org/iderudit/1064992ar

DOI : https://doi.org/10.7202/1064992ar

Aller au sommaire du numéro

Éditeur(s)

Les Presses de l’Université de Montréal

ISSN

1188-2492 (imprimé)

1200-5320 (numérique)

Découvrir la revue

Citer cet article

Hui, W. (1995). Humanism as the Theme of Chinese Modernity. Surfaces, 5. https://doi.org/10.7202/1064992ar
Résumé de l'article

Étudiant le discours humaniste des Lumières en référence à la Chine et à l'Ouest, cet essai ouvre à nouveau la question suivante : comment les intellectuels Chinois ont-ils assimilés les idées de l'Ouest et les ont-ils appliquées à leur propres pratiques sociales ? Il met en évidence les conceptions historiques qui sous-terndent l'humanisme occidental et trace l'évolution des discours humanistes chinois dans les termes de leur diffusion médiatique et de leur impact sur l'organisation du savoir ainsi que de leurs relations avec les concepts marxistes de mode de production. 


\title{
Humanism as the Theme of Chinese Modernity
}

\author{
Wang Hui \\ Institute of Literature, Beijing \\ wang@topaz.ncicl.ac.cn
}

Surfaces Vol.V.202 (v.1.0A - 01/11/1995)

Copyright for texts published in SURFACES remains the property of authors. However, any further publication should be accompanied by an acknowledgement of SURFACES as the place of initial publication.

ISSN: $1188-2492$

\section{ABSTRACT}

By examining humanist and Enlightenment discourse in reference to China and to the West, this essay reopens the question of how modern Chinese intellectuals assimilated Western ideas and applied them in their own social practice. It indicates the historical conceptions that underlie Western humanism and traces the evolution of Chinese humanist discourses in terms of their media of dissemination, their impact on the organization of knowledge, and their relationship to Marxist concepts of the mode of production.

\section{RÉSUMÉ}

Étudiant le discours humaniste des Lumières en référence à la Chine et à l'Ouest, cet essai ouvre à nouveau la question suivante: comment les intellectuels Chinois ont-ils assimilés les idées de l'Ouest et les ont-ils appliquées à leur propres pratiques sociales? Il met en évidence les conceptions historiques qui sous-terndent l'humanisme occidental et trace l'évolution des discours humanistes chinois dans les termes de leur diffusion médiatique et de leur impact sur l'organisation du savoir ainsi que de leurs relations avec les concepts marxistes de mode de production. 


\section{Humanism and Enlightenment: Two Modern Themes}

The Chinese scholarly and cultural world had just ended a debate on "humanistic spirit" when I received my invitation to this discussion of Humanistic Discourse. - From February to October, 1994, with "Humanistic Spirit" as the topic, a number of young scholars from the so-called humanities, e.g., literature, history, philosophy, and so forth , discussed in Reading, the most influential periodical in China, the following issues: the alleged crisis of humanities, the devaluation of humanist intellectuals, the declining value in the course of attaining market economy, the relationship between elite culture and mass culture, the relationship between the Chinese and the Western cultures, along with many others. These young scholars proclaimed themselves guardians of the humanistic spirit and rebuilders of integrity, and this led to a series of disputes: What is the humanistic spirit? Is humanistic spirit already lost? Does the false alarm that humanistic spirit is lost imply that people proposing this harbor an elitist arrogance if the humanistic spirit is merely a kind of knowledge and narrative? Although there is a considerable difference between the discussion on humanistic discourses in China and what we discuss about today and the methodology that we adopt, the common theme of humanism has already verified what Michel Foucault argues in "What Is Enlightenment?":

Humanism...is a theme or, rather, a set of themes that have reappeared on several occasions, over time, in European societies; these themes, always tied to value judgements, have obviously varied greatly in their content, as well as in the values they have preserved. Furthermore, they have served as a critical principle of differentiation. 1

The only point here that needs revision is that, as a theme, humanism does not reappear merely on several occasions in European societies, but also on certain occasions in other parts of the world, for instance, on many crucial occasions in twentieth-century China. Hence it raises the following questions: In the context of China, what are the distinguishing characteristics of humanism as a theme, and the changes of its content? What is the relationship and difference between this humanism and its counterpart that reappears in European societies? Why will Chinese scholars proclaim themselves the guardians of humanism after Foucault and his successors have penetratingly criticized humanism?

Before further analyzing the discursive formation of Chinese humanism, I want to indicate a fundamental fact: the Chinese term rewenzhuyi, though having its etymological source in Classic of Changes, one of the most ancient Chinese classics, has been generally accepted as a paraphrase of humanism frequently employed as a concept and theme in the cultural discussions in the twentieth century. To wit, humanism is, to Chinese scholars, merely one of the themes of the twentieth century, and a theme that was brought forth after the appearance of the Enlightenment and modernity in China. Therefore, what cannot be avoided in the discussion of the discourse of 
Chinese humanism is the extremely ambiguous relationship of humanism/ Enlightenment/modernity. In addition, this extremely ambiguous relationship came forth in the historical context of establishment of a modern nationstate and resistance to Western colonialism. Thus, discussions regarding humanism have to be entangled with forms of discourses like China/West, tradition/modernity, and so forth.

In "What Is Enlightenment?," Foucault tries hard to clarify the constantly ambiguous relationship between humanism and Enlightenment. At the same time arguing that humanism is one theme or a group of themes that reappeared in European history, he especially posits that we should not forget that the Enlightenment is "an event, or a set of events and complex historical processes," and that the Enlightenment merely appeared at a unique moment in the developmental period of European societies:

As such, it includes elements of social transformation, types of political institution, forms of knowledge, projects of rationalization of knowledge and practices, technological mutations that are very difficult to sum up in a word, even it many of these phenomena remain important today. $\underline{2}$

Nevertheless, in the context of China, it is difficult to demarcate explicitly humanism from the Enlightenment. It is because that "Enlightenment" has never been, in the context of China, a historical process as Foucault posits, but one theme or set of themes that reappears continuously in modern Chinese history. Although a paraphrase of the Enlightenment, the Chinese term Qimeng does not exclusively mean the historical movement in Europe in the eighteenth century. In the Chinese application of the term Qimeng, the whole modern European historical process after the eighteenth century has been set as the norms and targets of Chinese modernity. Moreover, Qimeng, which has been used to provide Chinese modernity with norms and targets, has become a spectrum of different themes, since there are completely dissimilar forms of interpretation of this European historical movement, and, again, all forms of interpretation are restricted by the historical conditions of the interpreters. Precisely as in the case of humanism, the theme of Qimeng has always been associated with value judgments and brought about quite obvious changes in its content. For instance, in the May Fourth New Culture Movement around 1919, the theme of Qimeng took the form of a revolt against traditions, the belief in science, and self-consciousness. In the New Enlightenment Movement from 1937 to 1945, the theme of Qimeng turned out to be the synthesis of "a patriotic movement, a movement of liberalism, and a movement of rationalism in the sense of cultural thinking." $\underline{3}$ In the Enlightenment trend of thought in the 1980s, the theme of Qimeng was, for one thing, criticism of orthodox Marxism and humanism clothed in Marxist terms.in this sense, although we will not confuse humanism and Qimeng, we cannot distinguish Qimeng from humanism as an event from a theme since both are themes that reappear time after time on crucial occasions in modern Chinese history, and both are interrelated, different from each other, or even in conflict with each other at times. In a certain sense, Foucault's extraordinary statement regarding humanism can also be applied to Qimeng. For example, we can imitate the ensuing remark of his: 
And it is a fact that ...what is called Enlightenment (humanism) has always been obliged to lean on certain conceptions of man borrowed from religion, science, or politics. Enlightenment (humanism) serves to color and to justify the conceptions of man to which it is, after all, obliged to take recourse. $\underline{4}$

Both themes were formed in the Chinese historical process in search of modernity, and both cannot be deemed, as Foucault asserts, an "event" or "historical process." Of course we cannot conclude consequently that Foucault's interpretation of Enlightenment/humanism is incorrect. What I precisely want to say is that the relationship between Enlightenment and humanism will vary conspicuously according to the historical context. Hence, Foucault's position does not touch the issues of Enlightenment/ humanism/modernity which could have, in the age of colonialism, nonWesternized characteristics of their own and their own unique relationship. In the context of China-one of the characteristics is the association of the local society and culture with the historical period of European colonialismthe Enlightenment as a European historical event was turned into a theme. As a result, the discourse of humanism and the Chinese Enlightenment have become two themes that are frequently interrelated and at the same time meld together.

\section{2. "Interculture" and the Three Chinese Translations of Humanism}

Humanism has three translations in Chinese: renwenzhuyi, rendaozhuyi, and renbenzhuyi. These three terms are interchangeable when they are employed for the Renaissance, the Enlightenment, and the philosophical traditions in nineteenth-century European history. In other words, these three concepts all include the understanding and interpretation of humanism in modern European history. What is more important, however, is that these three Chinese terms for the special objects in European history have become recurrent themes in modern Chinese history. Various discourses almost in conflict with each other are formed by using these three concepts as keywords. In the course of the discursive formation of Chinese humanism, there was a process of turning them into a theme, that is, to transform the special historical period and philosophical thinking in European history to essential themes in modern Chinese history. When humanism and other concepts were transplanted into the context of China by means of translation, their original definition underwent sensational changes and become the most energetic factors in modern Chinese cultural thinking. The process of using Chinese terms to transform special objects in European history to themes in modern Chinese society and culture indicates profoundly that the formation of modern Chinese culture involves a process of communicative action. This process of communicative action does not mean that between individual subjects, but that between cultural communities or language communities, to wit, a process of translingual practice. $\underline{5}$ Perhaps we should use a new term like "interculture" or "interculturality" for modern culture formed in this process. Habermas employs the concept of "intersubjectivity" to illustrate the feature that the behavioral subject cannot be isolated from other behavioral subjects. What 
he is concerned with seems to be, however, the communicative action between individual subjects in a special social community or language community instead of the communicative action between different language communities and cultural communities. Modern culture can be interpreted merely in the communicative action between cultures when we deem the process of language translation as the major aspect of modern cultural activities. Consequently we have to give consideration to Chinese cultural discourse.

Before going on to historical analysis, I will concisely elucidate the Chinese origin of the three Chinese terms renwenzhuyi, rendaozhuyi, and renbenzhuyi. On the one hand, the concepts of renwen and rendao are ancient terms in Chinese language, but, renwenzhuyi, rendaozhuyi and so forth are exactly modern themes, although people who employ these concepts often justify these themes in the sense of their ancient etymology. On the other hand, if we recognize that a certain nation's language must have its own independence, we cannot simply regard renwenzhuyi and rendaozhuyi as the plain translation of the various sorts of Humanism in European history, but consider this process of translation as a process of elucidation. In view of their use, to translate and interpret Humanism by means of different concepts indicates not only the users' understanding of European history and culture, but also their understanding of modern Chinese issues. The concept of renwen first appeared in the Section Ben, Classic of Changes: " To observe the heavenly culture (tianwen) to realize the changes of times, to observe the human culture (renwen) to educate the whole world." Kong Ying-da comments on the above passage, saying: "It says that the sage observes human culture, that is, poetry, history, rites, and music, and uses these to educate everyone in the world." Heavenly culture chiefly means natural phenomena, whereas human culture chiefly means cultural phenomena, especially education through rites and music. Hence, in contrast to the concept of renwen that means culture in the relationship between heavenly culture/human culture, the concept of rendao means the ethical norms that people should observe in a certain society. For instance, xici II, Classic of Changes remarks: "There is the heavenly way and the human way (rendao)." Notes on Mourning Customs, Classic of Rites also says: " To be close to one's parents, to honored, to treat kindly the elderly, and with a demarcation between the male and the female, these are the main issues of the human way." What is noteworthy is that in adopting the term renwenzhuyi to translate the culture of the Renaissance in Italy in the sixteenth century, with the concept of renwen involving, more or less, the ancient culture and the classics of the sages, the motive of the Chinese scholars is similar to that of the Italian humanists in the Renaissance who paid attention to the research of ancient culture, classics, and languages. Consequently, Chinese scholars translated "Humanities" as human courses or human studies (renwenxueke). The concept of rendaozhuyi is even more widely used, but, compared with renwenzhuyi which means culture or learning, rendaozhuyi especially means the thinking system with the human being at its center and the concepts of value regarding liberty, equality, and fraternity; it therefore has a more stressed value-orientation. Finally, the literal meaning of renbenzhuyi is to regard the human being as the fundamental factor, and is more employed for scholarly research calling itself anthropology, although it is also a term for the translation of 
"Humanism." In ordinary vocabulary, renbenzhuyi is far less adopted than renwenzhuyi and rendaozhuyi. This is why I will chiefly analyze the use of rendaozhuyi and renwenzhuyi.

In the May 4 New Culture Movement, rendaozhuyi and renwenzhuyi were two propositions that were almost opposed to each other and belonged to two opposing groups of thinking and literature, but the English original of the concepts of rendaozhuyi and renwenzhuyi that both of these two groups advocated was Humanism. Thus the two different translations of the same Western concept turned out to be two opposing themes in the process of becoming a theme. It involved not only the difference between the substantial objects in European history that these two translations incorporated (renwenzhuyi essentially involved the classical Chinese and Greek cultures in the special debate then, whereas rendaozhuyi chiefly involved the Renaissance and the Enlightenment), but also the Chinese users' attitude towards modernity. The two different Chinese translations of Humanism evidently indicate the existence of various discourses of humanism. In the period of the May 4 Movement, there were the discourse of humanism based on a narrative of time (tradition/modern) and the discourse of humanism based on the relationships of space (self/other).

The cultural group around the periodical New Youth stresses that all the attributes of modern European culture have prepared Europeans for power and progress culturally, whereas those attributes can hardly be found in "traditional" Chinese culture, therefore China was doomed, in modern times, to suffer poverty, backwardness, and vulnerability. Nevertheless, this backwardness is not a characteristic historically unchangeable: a nation that behaves collectively can improve this characteristic through adopting all the modern attributes of European culture. On one hand, humanism was regarded as the most important attribute in modern European culture, and, on the other hand, it was also deemed as a universal ideal of mankind.

Therefore, to the New Youth group humanism was almost equal to the antitraditional "New Culture." Obviously, the interpretation of humanism was transplanted into a narrative model in the sense of time, the difference between China and Europe was understood as the relationship between the advanced and the backward. Again, the change of this sort of relation moved in the future direction indicated by humanism. In this narrative model of time, humanism is not only the characteristic of modern European culture and the dynamics of human history including China, but also the final destination of the whole process of history.

The cultural group around Xue henq, another leading periodical at the time, was largely under the influence of Irving Babbitt. The members of this group deemed "expansion" as the major characteristic of humanism. European expansionism was culturally based on humanism with "expansion" as its chief feature. The expansion of humanism included "the expansion of human knowledge and the ability to control the natural world" and "expansion with emphasis on feeling" (fraternity and individualism). Also, the keystone of this sort of expansive philosophy of life was the so-called concept of progress. In view of criticism of modern European expansionism, the group of Xue heng suggested that the concept of renwenzhuyi meant the moderate, balanced, peaceful, and ordinary "universal human nature." $\underline{6}$ In the essays of the 
group of Xue heng, renwenzhuyi was defined as a "real culture" which did not belong to the Western world only, nor was it what China lacked only. It existed universally in both Western and Chinese classical cultures, especially in Chinese Confucian thinking and the spirit of ancient Greek civilization. Hence, renwenzhuyi of the Xue heng school drew, with its doubt about modern culture and nostalgia of traditions, a clear demarcation between it and the anti-traditional rendaozhuyi of the New Youth school. To link humanism with "expansion" indicates conspicuously the effort to define humanism in terms of spatial relationships, and this relationship of space is that of self/other. In the context of China at that time, it included the aspects of human being/nature, self/other, West/East, and so forth. This handling of humanism in the sense of space was a rejection of the modern teleology of time, and an exposition of the relationship of knowledge/power embodied in the discourses of humanism. Thus, the concept of renwenzhuyi became in this context a sort of anti-modern theme which sharply opposed the modern theme of rendaozhuyi.

In the "May 4" period, the rendaozhuyi discourse and the renwenzhuyi discourse directly opposed to and conflicted with each other around the issues regarding traditions and modernity. Nevertheless, they shared certain characteristics behind these sharp conflicts. In fine, rendaozhuyi and renwenzhuyi were regarded respectively by the different schools as an absolute and universal concept of value, not as knowledge or narrative in a special period or culture. Secondly, although all of them were professors, the Chinese advocators of either rendaozhuyi or renwenzhuyi were not depicting rendaozhuyi or renwenzhuyi within the norms of humanistic discourse. It was because the humanities in Chinese universities were not at that time the humanities in the Western sense. (The traditional Chinese taxonomy of classics, /pp. 13-14/ history, philosophers, and literary works was directly involved the structure of power in ancient Chinese society. Although this old taxonomy was gradually replaced by the new taxonomy of literature, history, philosophy, economics, and so forth, many subjects in Western social science and humanities, for example, psychology, pedagogy, and so on, had not, however, been offered at Chinese universities, or were just established. At the same time, the methodology of literature, history, philosophy, and so forth, was still following the norms of the ancient Chinese methodology dealing with classics, history, and literature. In addition, many scholars got their scholarly training in the old taxonomy of classics, history, philosophers, and literary works.) Thirdly, rendaozhuyi discourse and renwenzhuyi discourse were essentially spread by means of newspapers and periodicals which were run by the intellectual elite who wanted to arouse unawakened people.

In view of the above-mentioned fundamental features, we can clearly understand the elitist characteristics of both rendaozhuyi and renwenzhuyi discourses. Now we need to put forward the following questions: What is the relationship between rendaozhuyi discourse, renwenzhuyi discourse, and the social practice of the intellectual elite? What is the relationship between these discourses and the social regime? Discussions on these issues will involve a very complicated historical realm. This essay can merely discuss concisely certain key factors such as the abrogation of imperial examinations in late Qing Dynasty (1644-1911) and the change of position of 
the intellectual class in the social power structure. China in late Qing Dynasty had to learn from the Western education system because of the Western invasion, and in 1905 China finally abrogated the imperial examination system and thoroughly changed the relationship between the intellectual elite class and the Chinese political regime. Following the abrogation of the imperial examination system, the class of shi-oldfashioned scholars-disappeared from Chinese history. Also, the Chinese Confucian classics gradually lost their influence on society because of the abrogation of this system. Again, following the abrogation of this system, there appeared a large number of newspapers and periodicals run by intellectuals outside of the national regime, and they chiefly discussed the political situation and spread modern Western culture. At the same time, there developed gradually the system of modern university. Intellectuals would no longer enter the national regime through imperial examinations. On the contrary, they played the role of pioneers in newspapers and periodicals or entered the universities to receive a Western education. If it was true that the imperial examinations offered the means for the shi class to enter the social system, then to influence and control social power, we may say that modern intellectuals must influence society by means of newspapers and periodicals. The reform of the educational system and the introduction of Western social science and knowledge, which the newspapers and periodicals in late Qing Dynasty endorsed on a large scale, coincided with the process of establishing courses of social science and humanities in modern universities. The humanistic discourses that were essentially spread by newspapers and periodicals in late Qing Dynasty and modern times were formed in the process of the establishment of modern Chinese national country and social regime.

\section{The Contemporary Chinese Humanistic Discourse and Marxism}

The discourses of contemporary Chinese humanism can still be divided into rendaozhuyi discourse and renwenzhuyi discourse. It merits our attention that the discourses of Chinese humanism do not have a significant relationship with the courses of the social sciences and humanities in Chinese universities. It is because the Chinese discourses of social sciences and humanities were established with the Marxist mode of production as the core, not with "human being" and human self-understanding as the core. For a long time, anthropology, psychology, sociology, and other courses were banned as pseudoscience. In the years before 1980, there were no Western courses of humanities, and there were merely courses of Chinese social sciences that included political-economics, philosophy, history, literature, and so forth. All those courses were based on the model of economic basis/ superstructure and ideology. They criticized from every angle the abstract concept of human being and humanity that the eighteenth-century European humanism advocated, thus undermining the theoretical basis of anthropology. Hence, the contemporary Chinese humanistic discourses were formed in its opposition to Chinese social sciences. When Marxism was still a national ideology, this sort of discourse of humanism adopted the form of Marxist humanism. 
To discuss the meaning of contemporary Chinese Marxist humanism, we must first understand the historical relationship between Marxism as the Chinese national ideology and modernization. The theory of modernization interprets modernization as the development of science and technology, and the sensational change from a traditional agricultural society to urbanization and industrialization. As the theory of modernization interprets the fundamental norms of modernization in view of the development of European capitalism, the process of modernization is, therefore, often interpreted as the process of capitalization. It is, however, somewhat different in the case of China. It is because the issues of modernization of contemporary China were not suggested by Chinese Marxists only, and Chinese Marxism itself is a modernization ideology. Moreover, the Chinese socialist movement not only has the realization of modernization as its basic target; the movement itself is the main characteristic of Chinese modernity. The popular concept of modernization in contemporary China chiefly means the transition and development from the backward state of politics, economy, military force, and science and technology to a more advanced state. Nevertheless, this concept is not merely a technological target or the formation of the Chinese national state and the bureaucratic system, but also means the conception of history and the world view of a certain teleology, a mode of thinking to interpret its own social practice in view of this final target, and a modern attitude to associate the meaning of selfexistence with the time that this self-existence belongs to. It is precisely because of this that the concept of socialist modernization not only indicates the difference between the socialist mode of Chinese modernization and capitalist modernization, but also offers a whole set of value concepts. Socialism in Mao Ze-dong's sense is, on the one hand, a sort of modern ideology and, on the other, a critique of European and American capitalization. This critique is not, however, a critique of modernization itself; on the contrary, it is a critique of modernized capitalization based on revolutionary ideology and nationalism. Thus, in view of value concepts and the concept of history, Mao Ze-dong's socialist thinking is a sort of modernization theory against capitalist modernity.

Since 1978 Chinese Marxist humanism appearing within the Chinese Communist Party and among intellectuals has tried to employ the concepts of "human being" and "humanity" to remold Marxism as the national ideology whose keystone is the mode of production. In this period, the main feature of humanistic discourses has been to remold Marxism with humanism, and to use this remolded Marxism to criticize Mao Ze-dong's anti-modern ideology of modernization, thus offering a theoretical basis for Deng Xiao-ping's socialist reform movement. This trend of thought was part of the Chinese "thinking-liberating movement" then. Humanist Marxism criticizes Mao's socialism for forgetting the thinking about human freedom and liberation in Marxist theories, and for the resulting cruel social dictatorship in the name of "people's democratic dictatorship." However, this humanist Marxism also conflicts with Deng's socialist reform thinking. The essential theoretical issue that the Chinese humanist Marxism is concerned with is the issue of alienation that Marx discussed in his Economic and Philosophical Manuscripts of 1844. In his early years, Marx inherited the concept of alienation in Western philosophy suggested by Ludwig Feuerbach and others, and applied this concept to the analysis of capitalist relations of 
production, especially in the analysis of labor in the process of capitalist production. The concept of alienation in the Marxist sense is, for one thing, the alienation of labor in the capitalist relationship of production. The Chinese humanist Marxism frees the Marxist concept of alienation from the historical context of criticizing capitalist modernity, and turns this concept into a critique of Mao's socialism. Essentially, this trend of thought criticizes Mao's socialism, especially his autocracy as the evil historical legacy of traditional feudalism. Exactly as the critique of religion by Western humanism after the Renaissance, /pp. 17-18/ the Chinese humanist Marxism's critique of Mao's socialism expedited the "secular" movement in Chinese society: the development of the capitalist market process. In this particular context, Marx's critique of Western capitalist modernity has been changed to a sort of Marxism as a modernization ideology, and has thus become an important component of contemporary Chinese Enlightenment thinking.

The discourse of humanism as a contemporary theme has undergone the process of change from a marginal discourse to a mainstream discourse. This process is related to the fate of the Chinese Enlightenment in the everchanging contemporary Chinese context. Around 1985, the Chinese Enlightenment no longer appealed to the fundamental principles of Marxism, but derived inspiration directly from early French Enlightenment and British and American liberalism. To interpret Mao's socialism as the historical tradition of feudalism is not only the stratagem of struggle on the part of the Chinese Enlightenment, but also makes this Enlightenment acquire a self-understanding: it is a social movement similar to that of the European bourgeois class against religious dictatorship and feudal aristocracy. What was covered up in this self-understanding is the common target of value and the mode of historical understanding shared by humanism as a modernization ideology and Marxism as a modernization ideology: the belief in progress, the promise of modernization, the historical mission of nationalism, and the prospect of the Great Harmony of freedom, equality, especially the modern attitude to associate the meaning of selfstruggle and existence with the transition to the future, and so forth.

The Chinese Enlightenment in the 1980s is a wide and complicated social trend of thought, including in the theme of "Enlightenment" various dissimilar factors of thought with the common target of criticizing the existing socialism. The discourse of humanism is an organic component of this trend of thought with "Enlightenment" as its theme. Therefore, to understand the historical implication of the discourses of humanism one must first understand the multifarious themes of Chinese Enlightenment and their interrelationships: in the field of economics, by means of the critique of Mao's planned socialist economy, to reaffirm the justified position of the market economy and the law of value in the process of commodity circulation, thus to interpret market system and private ownership as the universal formation of modern economy, and finally realize the target of bringing Chinese economy into the world capitalist market; in the field of politics, to require the re-establishment of the systems of formalized laws and modern civil officials, to establish gradually, by means of expanding the freedom of press and speech, the parliamentary system of safeguarding human rights and restricting the power of rulers. All the above political and 
economic considerations take the discourses of humanism as their cultural basis. We may say that Chinese scholars of humanities adopt the concepts of humanistic value to re-establish a new picture of both the world and Chinese history, thus to honor modern Western society as the highest norm for Chinese social reforms and as a means to tie the critique of Mao's socialist practices to a teleological conception of history with subjectivity of the human being as the end-result, and employing this concept of subjectivity as the philosophical basis of individualism in the field of social ethics.

Obviously, contemporary Chinese humanism is an important component of the ideology of the Chinese "reform." Its critical spirit is gradually disappearing following the deepening development of market forces in Chinese society. It is because the Chinese Enlightenment is facing an already capitalized society: the market economy is becoming an increasingly important economic formation, and the Chinese socialist economic reform has already brought China into the process of production and trade of global capitalization.

The renwenzhuyi discourse has, however, re-appeared in the Chinese intellectual world precisely when rendaozhuyi discourse is becoming the mainstream discourse. In discussions about humanistic spirit in Readinq in 1994, what the participants were concerned with was the so-called "declining value of the humanistic spirit" which caused the loss of critical spirit in humanistic discourses, and "humanistic spirit" was considered as "the inner basis of all humanities." What is more, this "loss of humanistic spirit" is only an indication of stunted growth and animalization of the intellectuals' spirit. Thus, they called for establishing a "new tradition" of intellectuals. The contemporary Chinese renwenzhuyi scholars insist that renwenzhuyi must be a sort of culture of the intellectual elite and a concern for value that will also be the basis for the intellectual elite to insure the dignity of the humanities, the social position of pioneers, and the leadership of culture. There is not much difference between the renwenzhuyi scholars and the rendaozhuyi scholars in view of their insistence on associating "humanism" with "Enlightenment" or in the elite attitude of "Enlightenment." The quintessential characteristic of renwenjingshen (humanistic spirit) discourse is the anxiety about all cultural issues in the wake of the market process. They tried to re-establish the ethical value destroyed by the market process by means of reestablishing the dignity of humanities scholars. They assumed the theme of "declining humanistic spirit" and blamed this "decline" for all political, economic and cultural crises. As a result, they were determined to restore the dignity of classical philosophy and reestablish the value of humanities.

Nevertheless, renwenzhuyi scholars did not offer new content for their "humanistic value." They united all political, economic, and cultural issues into a new issue, that is, the "loss of humanistic spirit." This indicates that they were unable to analyze the complicated social process, and could only show an ethical attitude by means of this topic. As a matter of fact, renwenzhuyi scholars are merely rendaozhuyi scholars who went astray. They could not surpass the abstract humanistic topic to elucidate the social process that confronted them. To their issue, I want to put forward not only this question: "Is humanistic spirit lost?" but also "Why is humanistic spirit 
lost?" It seems that they are preachers of renwenzhuyi, but, preachers could be God if there were no God. Very obviously, the theme of renwenzhuyi cannot actually re-establish independent principles of critique, and cannot offer basis of reflection for the spiritual freedom which they are dreaming of.

\section{A Brief Conclusion}

Chinese humanism is one single or various modern themes. This or these modern themes have different content on different occasions, but have prefabricated the teleological conception of history and the concept of the human being. In the historical context of China, the progressive conception of history was established with Western society as its norm. The image of the human being established in this conception of history included an understanding of Western individualist culture, and was again molded by Western individualist knowledge. Though searching for the source of value in tradition, the renwenzhuyi scholars' responses were quiet about to the issues regarding the modernization of China.

Chinese humanistic discourses chiefly adopt newspapers and periodicals as their medium. In a very long historical period, there were no courses of humanities in the Western sense. Chinese philosophy, history, literature, and other branches of the social sciences established, around the core of the Marxist mode of production concept, a system of knowledge based on the following fundamental concepts: the economic basis, the superstructure, ideology, class, class struggle, and so forth. This system of knowledge afforded support in various fields to the national ideology. Contemporary Chinese humanism and the concept of the human being were, at first, directed against Marxism which occupied a dominant position in ideology. Now, however, the essential objects of criticism of the discourse of humanism are the capitalist market and its individualistic concept of value that humanists looked forward to in the past. The discourses of Chinese humanism are ever-changing and conflicting with each other, and their meaning should be understood in the substantial context and practices.

Chinese humanism as a theme related to Chinese Enlightenment has always belonged to elitism. Its reflection and criticism of many issues are established on this implied supposition: Humanism is a universal value that must be spread to the whole society with the intellectual elite as the medium.

"Why is humanism lost?" This question will lead us to the substantial process of social practices and various complicated cultural relationships. The theme of humanism will be queried-but not denigrated-and the theme itself must first be investigated in the relationships between discourse and discourses, discourses and practices, and discourses and social system.

\section{NOTES}

ATranslated by Edward Peng 
1Michel Foucault: "What is Enliqhtenment?," The Foucault Reader, ed. Paul Rabinow (New York: Pantheon Books, 1984), p. 44.

2IIbid., p. 43.

3He Gan-zhi: Zhonqquo qimenq yundong shi (Shanghai: Shenghuo shudian, 1947), p. 205.

$\underline{4}$ Michel Foucault: "What Is Enlightenment?," The Foucault Reader, ed. Paul Rabinow (New York: Pantheon Books, 1984), p. 44.

$\underline{5}$ See Lydia H. Liu's article entitled "Translingual Practice: The Discourse of Individualism between China and the West," Positions, volume 1, number 1, Spring 1993, Duke University Pess, 1993.

$\underline{6}$ "Babbitt's Talks on Chinese-Western Education of Humanities," Trans. Hu Xian-su, Xue heng 3, pp. 1-12. 